\title{
Sustainability Analysis of Palm Oil as Implications for Price Decreasing of FFB Sei Kepayang Region
}

\author{
Iskandar Zulkarnaen, Paduloh, Ika Yunita,
}

\begin{abstract}
The price of oil palm is a challenge posed by oil palm farmers at the moment, a decrease in the price of oil palm can be calculated by blocking from abroad the Indonesian CPO, opening new land and increasing the current budget of the price of oil palm to be very cheap when compared to the previous 2 years. This cheap price has an impact on reducing the allocation for plant maintenance which will also have a direct impact on quality and will have another impact. For this reason, research on the impacts of oil palm on sustainability is needed and factors that can be proposed for improvement. This research uses SSM, AHP and ISM methods to get more complete results. SSM research results indicate the need for improvements to infrastructure to transport oil palm yields, a guarantee of the selling ${ }^{1}$ price of FFB and improvement in the quality of human resources of oil palm farmers is very necessary. ISM results show government, farmer groups, farmer groups, and cooperatives can join together to improve the quality of oil palm products, join together to send crops directly to PKS to get better prices with the support of cooperatives and local governments. Further research from this research is the formation of models that are produced according to ISM results.
\end{abstract}

Keywords: Oil palm; FFB; Sustainability; Selling Price; SSM; AHP; ISM.

\section{INTRODUCTION}

$\mathrm{T}$ The selling price of Fresh Fruit Bunches (FFB) is an obstacle faced by oil palm farmers today, where the selling price reaches the lowest level at the farmer level. With these price conditions, farmers cannot cover production costs and the cost of harvesting FFB. So that many farmers reduce care that will directly affect the amount of production and quality of FFB. Previous studies discussing the price of FFB have been conducted [1] showing that there is a fairly high difference between the price of oil palm on the global market before and after the resolution, [2] conducting proof of prices and costs has a significant effect on farmers' incomes. [3] shows that the price, distance, and transportation costs of FFB influence sales volume. This is in line with the existing conditions in the field, where the further the distance of the plantation from the mill the selling price of fresh fruit bunches of oil palm is also getting

Revised Manuscript Received on January 5, 2020.

* Correspondence Author

Iskandar Zulkarnaen1*, Department of Industrial Engineering, Bhayangkara Jakarta Raya University. E-mail: iskandar.zulkarnaen@dsn.ubharajaya.ac.id

Paduloh, Department of Industrial Engineering, Bhayangkara Jakarta Raya University. E-mail: paduloh@dsn.ubharajaya.ac.id

Ika Yunita, Department of Industrial Engineering, Bhayangkara Jakarta Raya University. E-mail: ikayunita0512@gmail.com cheaper, and farmers also cannot sell directly to palm oil mills due to the minimum amount of purchase of FFB that is difficult for farmers to meet.

This research will use the SSM, AHP and ISM methods to analyze the actual events so that a conclusion can be made. SSM is a method of Peter Checkland [4], [5] using SSM to obtain the ideal and sustainable model for the fishing management industry. [6] used SSM to create a conceptual model for skipjack fish problems and find the source of the problems encountered. This research aims to study the impact of the decline in the price of FFB on the sustainability of the palm oil supply chain, also, it needs to be studied the right solutions that can be done for farmers so that they can overcome the impact of the decline in prices. The research uses the method of direct interviews with experts and farmers in Sei Kepayang, Medan.

\section{RESULTS AND DISCUSSION}

\section{A. Soft System Methodology}

In its application, SSM is divided into two main stages namely the real world with five steps and system thinking with two steps. So in general, SSM has 7 stages of steps namely reviewing unstructured problems, expressing problem situations, building problem definitions related to problem situations, constructing conceptual models, comparing conceptual models with problem situations, establishing appropriate and desirable changes and taking corrective actions. for the problem.

\section{1) Definition}

The first and second stages in SSM [7], [8] are part of the real-world stage. At this stage of the real world, problems were identified and found at the research location. RDs (Root definitions) are structured descriptions of a system of human activities that are relevant to the problem situation of concern in action-based SSM research. RDs are the only way to describe the system to help the system modeling process. Checkland and Poulter (2006) [4] suggest that the general $\mathrm{PQR}$ formula be used in preparing an RDs. The PQR formula is to work on $\mathrm{P}$ with $\mathrm{Q}$ to realize $\mathrm{R}$. In the context of research on the development of FARMER Palm Oil using rich picture, 3 (three) RDs are produced by paying attention to the CATWOE element to analyze the transformation process, namely:

(1) Sustainable Palm Oil agro-industry supply chain

(2) Productivity of Oil Palm

Farmers

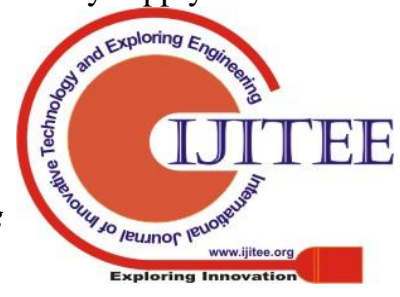


(3) Competitiveness

Table-I: CATWOE and PQR on increasing competitiveness

\section{CATWOE}

C (Customer)

A (Actors)

T (Transformation)

W (Weltanschauung)

O (Owners)

E (Environment)
Consumers, distributors, retailers.

Farmers, collectors, palm oil mills, the Government, Oil Palm Research Institute

Achieving sustainable palm oil Agroindustry

Maintaining FFB supply with good quality and quantity by market demand, without any environmental impact to improve the welfare of farmers and communities.

Farmers, PTPN

Government support for the availability of good seedlings, cheap seedlings, easy capital and guaranteed price of oil palm, increasing the amount of oil palm production without opening new agricultural land.

\section{TEST PERFORMANCE}

\section{PQR}

Systems owned and operated by estate managers, industry managers, distributors, and supported by Government policies in ensuring the sustainability of sustainable Palm Oil Agro-Industry (P) that can be realized through a good system of Selling Price Assurance, production planning, inventory, transportation, and integrated distribution (Q) to increase productivity and improve the welfare of farmers and the community $(R)$.

\section{Table-II: Build Conceptual Models}

Efficacy (E1) Interaction and cooperation with the basis of attachment in improving HR skills and Selling Prices.

Efficiency (E2) Using HR, financial resources, and minimum time

Effective (E3) Achieving improvement in the quality of human resources to improve the quality/quality of good palm oil.

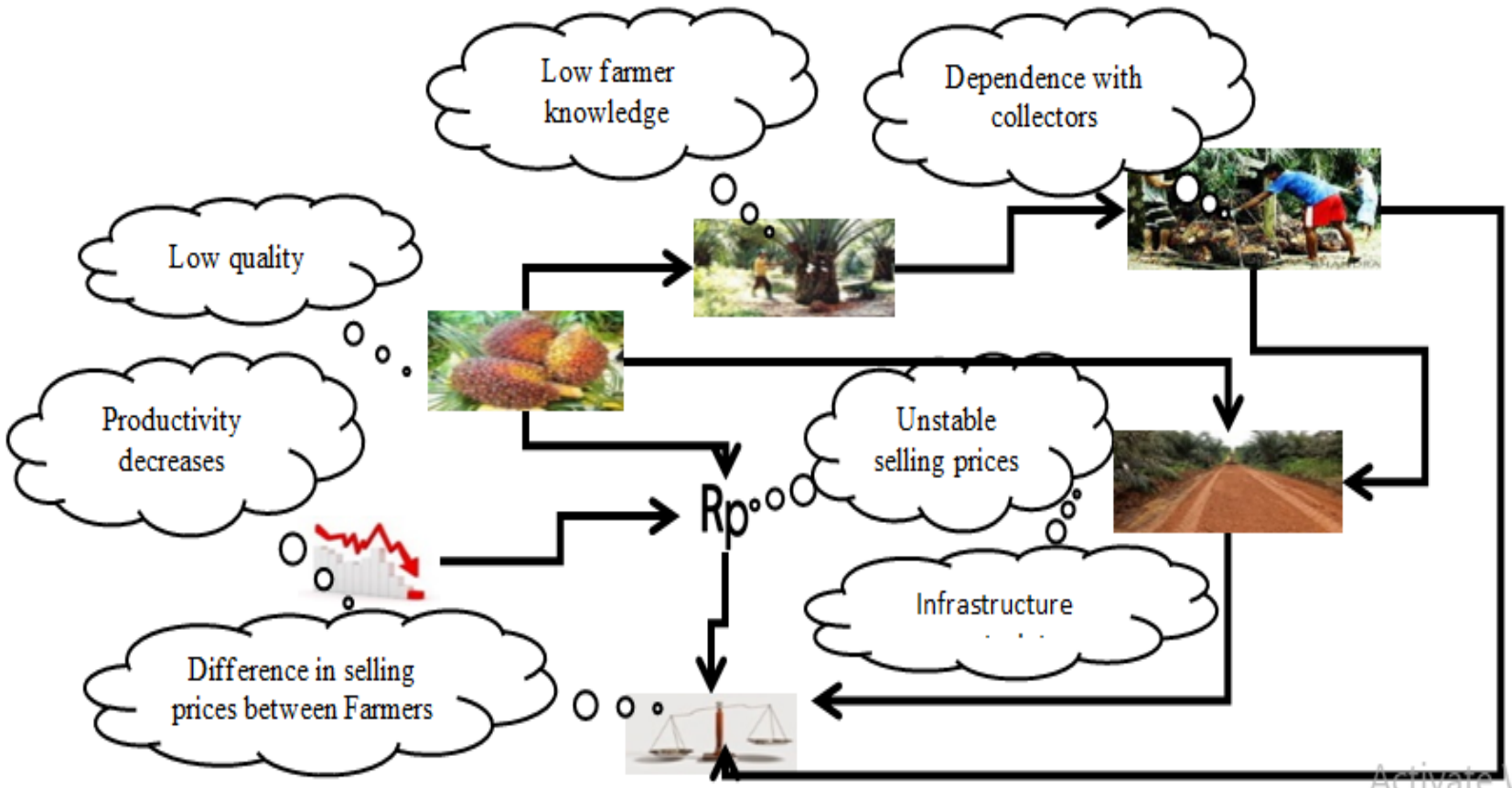

Fig 1. Rich Picture The problem of oil palm

\section{B. Build Conceptual Models}

Increased Palm Oil Productivity and competitiveness of oil palm farmers can be done with a series of activities seen in the conceptual model in Figure 2. The system activities in the conceptual model of improving the quality of human resources are as follows:

a. Guaranteed good selling prices for farmers

b. Farmers can establish and build relationships with financial/capital institutions, educational / training institutions. c. Farmers can form discussion groups to share experiences dealing with problems in agriculture. This group can be in the form of farmer groups.

d. As a result of the discussion, farmers are expected to get assistance in training/training in improving the quality of human resources.

e. Furthermore, with this interaction, Farmers are also expected to be able to collaborate with financial/capital institutions as well as education/training institutions in the provision/fulfillment of special budgets or the allocation of time and

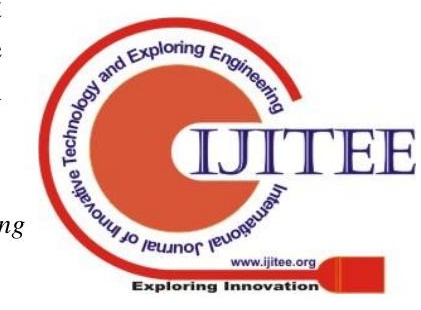


energy for the education/training skills of their employees.

f. With the availability of a special budget for activities to improve human resource skills, business actors/farmers can collaborate in education/training with educational / training institutions, conduct comparative study/apprenticeship activities for their employees to similar processing units that are already advanced.

g. Furthermore, with the improvement in the quality of human resources, it is expected to be able to achieve the goals and objectives of the company to support the competitiveness of Agriculture.

The success or failure of this conceptual model can be measured through the following criteria

Focus

Causative

Factor

Alternative

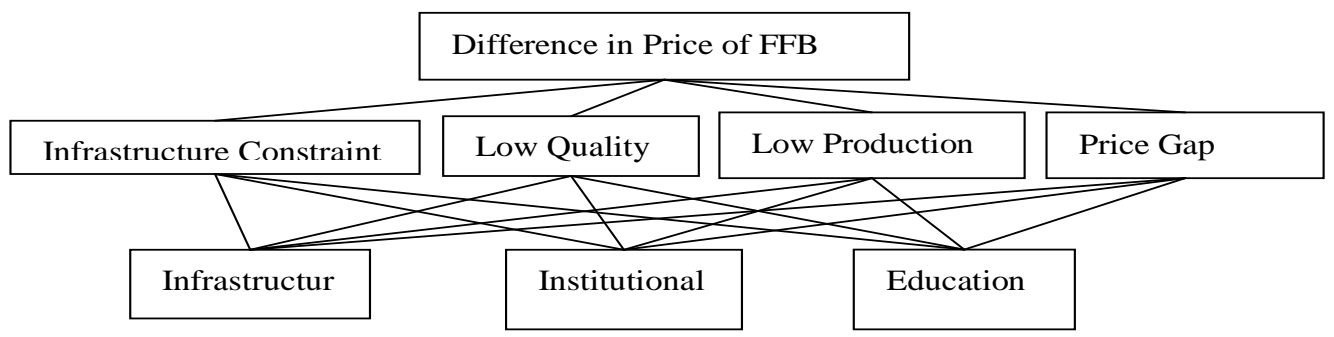

Fig 2. Hierarchy Structure

\section{Establish desirable changes}

SSM is based on problem-solving. The Recommendation for Improvement is to Develop Downstream Industries in Indonesia that can absorb the production of palm oil so that farmers get a guarantee that the oil they produce will be absorbed at a good price. Conduct training to improve Farmer Productivity and Awareness of the importance of Occupational Health and Safety, through government supervisory agencies. Besides, infrastructure needs to be improved so that distribution costs become cheap.

\section{Corrective Action on Problems}

The policy for the development of FARMERS Palm oil must be supported by appropriate policies by the local government and the Central Government, educational or training and capital institutions, one of which is through strategies to improve the quality of Farmers' HR, and actions that can be taken:

a. Guarantee a good selling price so that farmers can carry out maintenance activities for their plantations.

b. Provide adequate infrastructure so that transportation costs can be reduced as little as possible.

c. Establish and build relationships with financial/capital institutions, educational / training institutions, etc. for recognition of the existence of institutions.

d. Hold discussions to get input on HR skills from all parties involved

e. Obtain training/training of $\mathrm{HR}$ skills in financial institutions/capital, educational / training institutions, etc.

f. Provide a special budget for human resource skills improvement activities, in collaboration with financial institutions/capital, large business units, etc.

g. Collaborating with educational / training institutions, comparative studies, etc.

h. Improving the quality of human resources to support the competitiveness of farmers

\section{E. Review Unstructured Problems}

Information is obtained based on interviews with oil palm agro-industry actors, various kinds of information are obtained which are unstructured problem situations. The results of the collection and interpretation of information will provide an overview of the problematic situation in the research context. The results of the interview are as follows:

a. Palm oil prices have risen.

b. The price disparity is far between farmers, collectors, and palm oil mills.

c. The difficulty of infrastructure in oil palm plantations, so that when the rainy season comes, farmers are very difficult to transport crops.

d. The low ability of farmers so that errors occur in the selection of seeds, errors in purchasing fertilizers, errors in tree care and the environment.

e. Low knowledge of farmers about palm oil downstream products.

f. Low awareness of farmers regarding work safety and health.

g. Productivity Production is uneven at harvest and tends to below.

$h$. Increasing the amount of production by increasing product quality.

i. Prevent forest clearing for new oil palm lands.

\section{F. Expressing the problem situation}

The development of ideas through systematic problematic situations is based on information obtained. Furthermore, the unstructured problem situation is broken down into problems so that it becomes structured problems through rich picture. The results of the study in the field found problematic situations are Low Productivity of Farmers and Low Palm Oil Prices.

\section{G. Analytical Hierarchy Process}

Based on the results of the expert questionnaire using the Analytical Hierarchy Process (AHP) [9][10], a pairwise comparison between causative factors as controls and 
alternative solutions will be taken. Figure 3 shows the hierarchical structure of the alternative solution model in dealing with the price difference of Fresh Fruit Bunches (FFB) in the supply chain in Sei Kepayang, North Sumatra.in the hierarchical structure, there are four factors causing differences in FFB prices in farmers, namely the difficulty of infrastructure (I), low quality $(\mathrm{Q})$, low production yield $(\mathrm{P})$, and the dependence of farmers with collectors/agents (A), so there are four elements. that must be compared. The calculation and determination of consistency for pairwise comparisons between the main criteria are as follows:

Step 1: Arrange a pairwise comparison matrix

AHP is a pairwise comparison method that compares in pairs a homogeneous thing so that the things being compared will be easier and more objective. A pairwise comparison matrix between criteria can be seen in Table 4.

Table-IV: Pairwise Comparison Between Criteria

\begin{tabular}{ccccc}
\hline Criteria & $\mathbf{I}$ & $\mathbf{Q}$ & $\mathbf{P}$ & $\mathbf{A}$ \\
\hline $\mathbf{I}$ & 1.0000 & 0.3333 & 2.0000 & 0.2500 \\
$\mathbf{Q}$ & 3.0000 & 1.0000 & 3.0000 & 0.3333 \\
$\mathbf{P}$ & 0.5000 & 0.3333 & 1.0000 & 0.2500 \\
$\mathbf{A}$ & 4.0000 & 3.0000 & 4.0000 & 1.0000 \\
\hline
\end{tabular}

Table-V: Alternatives Ranking Results

\begin{tabular}{ccc}
\hline Alternatives & Weight & Ranking \\
\hline Infrastructure & 0.1062 & 3 \\
Institutional & 0.6588 & 1 \\
Education & 0.2151 & 2 \\
\hline
\end{tabular}

Based on the results of the calculation of alternative priorities in the best solution above shows that Institutional is the best alternative method based on the perceptions of the decision-makers viewed from causative factors: dependence farmers with agents, the low quality, infrastructure constraint, and low production yield.

\section{H. Interpretive Structural Model}

Based on the results of the AHP that institutions are the best alternative, further discussions are held with experts and related parties using ISM [7], [8]. From the results of discussions with experts and related parties, institutional sub-elements were obtained that played a role in advancing the welfare of oil palm farmers. The institutional sub-elements involved include the Central Government, Regional Governments, Entrepreneurs, Gapoktan, Farmers Groups, Cooperative, and Universities. From the results of the questionnaire that was filled in by the respondents, SSIM Tables were then made using ISM Software. As shown in Figure 4. Furthermore, based on Figure 4 then made in the form of a Reachability Matrix (RM) table. Thus, the results obtained as in Figure 5.

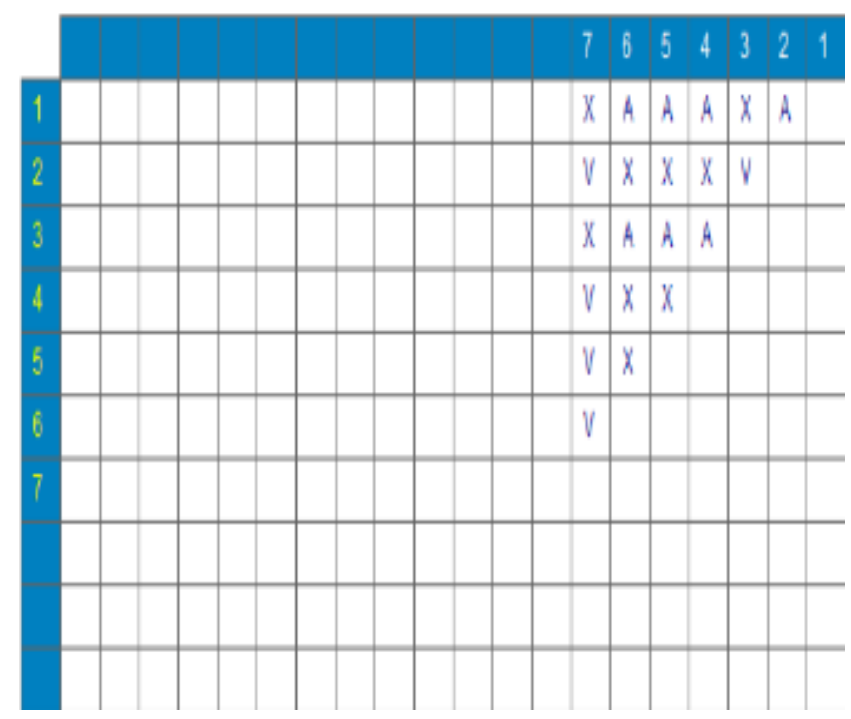

Fig 3. Making Structural Self Matrix Interaction Matrix (SSIM)

\begin{tabular}{lllllllll|l|l|l|l|l}
\multicolumn{1}{c}{1} & 2 & 3 & 4 & 5 & 6 & 7 & $\mathrm{DP}$ & \multicolumn{2}{l}{$\mathrm{R}$} & \\
\hline 1 & 1 & 0 & 1 & 0 & 0 & 0 & 1 & 3 & 2 & & \\
\hline 2 & 1 & 1 & 1 & 1 & 1 & 1 & 1 & 7 & 1 & & \\
\hline 3 & 1 & 0 & 1 & 0 & 0 & 0 & 1 & 3 & 2 & & \\
\hline 4 & 1 & 1 & 1 & 1 & 1 & 1 & 1 & 7 & 1 & & \\
\hline 5 & 1 & 1 & 1 & 1 & 1 & 1 & 1 & 7 & 1 & & \\
\hline 6 & 1 & 1 & 1 & 1 & 1 & 1 & 1 & 7 & 1 & & \\
\hline 7 & 1 & 0 & 1 & 0 & 0 & 0 & 1 & 3 & 2 & & \\
\hline $\mathrm{D}$ & 7 & 4 & 7 & 4 & 4 & 4 & 7 & & & & \\
\hline $\mathrm{L}$ & 1 & 2 & 1 & 2 & 2 & 2 & 1 & & & & \\
\hline
\end{tabular}

Fig 4. Reachability Matrix (RM)

Then, based on the results of the interpretation of the Reachability Matrix (RM) matrix, the Driver-Power Dependence Diagraph obtained in Figure 6

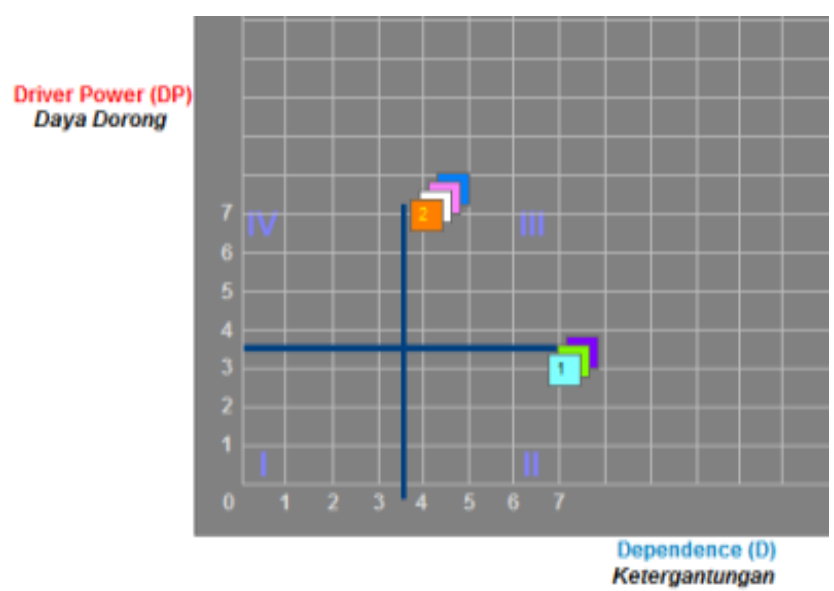

Fig 5. Power Driver - Dependency Mapping 
In Figure 5. Shown, there is no institutional element in sector I (Autonomous), central government elements (1), entrepreneurs (3) and tertiary institutions (7), are in sector II (Dependence), Gapoktan Element (5), Farmer Groups (4), Local Government (2) and Cooperative (6) are in sector III Strong driver-strongly dependent variables (Linkage), There is no institutional element in sector IV Strong driver-weak dependent variables (Independent). Gapoktan (5), Farmer Groups (4), Local Government (2) and Cooperative (6) are in sector III Unstable driver-strongly dependent variables (Linkage) which have the understanding that the 4 institutions involved in the sub this element is a benchmark that must be studied carefully because it can have an impact on other sub-elements including its influence can have a very significant impact on the system or has a high driving force but has a high level of dependency. While elements of the central government (1), entrepreneurs (3) and universities (7), are in the dependent sector or sector II. The three sub-elements in this sector, are sub-elements that have a very high dependence on other sub-elements but have a low driving force.

In other words, if these institutions are well-formed and fostered they will have a positive impact on farmers not only in terms of handling differences in FFB prices but can improve farmers' welfare in the programs to be run by these institutions, but if the institutions do not work in both as expected will lead to failure in efforts to deal with the problems faced by farmers.

\section{CONCLUSION}

Improvements to the Infrastructure for transporting FFB, guarantee of the selling price of FFB and Improving the quality of human resources of palm oil farmers is very necessary. This can increase the ability and competence of small farmers, which in turn will be able to produce good quality FFB that can compete with large plantations which will ultimately have an impact on improving the welfare of small farmers. Suggestions from researchers for the government is that infrastructure improvement is a problem that cannot be delayed anymore, besides the role of agricultural supervisors is needed to improve the quality of farmers. Further research that must be done is to create an appropriate institutional model so that farmers do not depend on collectors and prices can be distributed fairly.

\section{REFERENCES}

1. A. D. Yonanda, F. I. Administrasi, and U. Brawijaya, "Sawit Dunia Dan Ekspor Kelapa Sawit Indonesia ( Studi pada Negara Belanda , Spanyol, Cina dan India periode Agustus 2016 - Oktober 2017 )," vol. 72, no. 2 , pp. 234-242, 2017.

2. R. S. A. Rahman, Adlaida Malik, "Kebijakan Penetapan Harga Tbs Kelapa Sawit Pola," vol. 1, no. 1, pp. 87-99, 2018.

3. R. A. Hadiguna, "Model Penilaian Risiko Berbasis Kinerja untuk Rantai Pasok Kelapa Sawit Berkelanjutan di Indonesia,” J. Tek. Ind., vol. 14, no. 1, 2013.

4. F. P. Wheeler and P. Checkland, "Systems Thinking, Systems Practice: Includes a 30-Year Retrospective," J. Oper. Res. Soc., vol. 51, no. 5, p. 647, 2006.

5. S. Syukhriani, T. W. Nurani, and J. Haluan, "Model Konseptual Pengembangan Perikanan Tongkol Dan Cakalang Yang Didaratkan Di Kota Bengkulu," J. Teknol. Perikan. dan Kelaut., vol. 9, no. 1, pp. 1-11, 2019.

6. S. C. Batubara, M. S. Maarif, Marimin, and H. E. Irianto, "Achieving sustainability in capture fishing industry based on the regional characteristics," Int. J. Supply Chain Manag., vol. 5, no. 3, pp. 40-60, 2016.

7. S. Di, S. E. I. Kepayang, and S. Utara, "Pemodelan Kelembagaan Dengan Ism Pada Rantai Pasok Berkelanjutan Kelapa,” 2019.

8. S. Kumar, S. Gorane, and R. Kant, "Modelling the supplier selection process enablers using ISM and fuzzy MICMAC approach," J. Bus. Ind. Mark., vol. 30, no. 5, pp. 536-551, 2015.

9. R. Dwiyana, F. D. Sitania, and D. K. Rahayu, "Pemilihan Supplier Tandan Buah Segar (TBS) Menggunakan Metode Analytical Hierarchy Process (AHP) dan TOPSIS," no. November, pp. 89-98, 2017.

10. R. Purnomo and M. Widyantoro, "Analisis Luas Lahan Kelapa Sawit Menggunakan Metode FuzzyAHP Terhadap Resiko Pelaku Usaha,” no. x, pp. 1-7, 2019

\section{AUTHORS PROFILE}

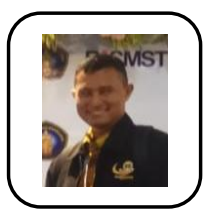

Iskandar Zulkarnaen, Lecturer at Bhayangkara Jakarta Raya University

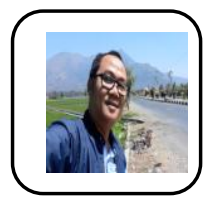

Paduloh, Doctoral Student at IPB University and Lecturer at Bhayangkara Jakarta Raya University, has publication for Reverse supply chain, clustering with K-Means and DBSCAN, matthematical modeling, artificial intelegent.

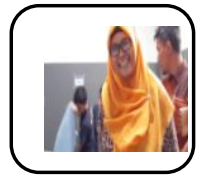

Ika Yunita, Student at Bhayangkara Jakarta Raya University. 